\title{
SOME OBSERVATIONS ON THE PHARMACOLOGY OF $\propto$-METHYLDOPA
}

\author{
BY \\ M. D. DAY* AND M. J. RAND \\ From the Department of Pharmacology, School of Pharmacy, University of London, \\ Brunswick Square, London, W.C.I
}

(Received August 10, 1963)

\begin{abstract}
$\alpha$-Methyldopa in high concentrations impaired the responses of rabbit isolated ileum and guinea-pig isolated vas deferens to stimulation of the sympathetic nerves and to noradrenaline, but these preparations taken from animals previously treated with $\alpha$-methyldopa showed no sign of impairment. Contractions of the cat nictitating membrane were reduced but not abolished by $\alpha$-methyldopa. In cats, dogs and rats, pressor responses to noradrenaline were usually slightly increased by $\alpha$-methyldopa. Pressor responses to tyramine were not affected consistently. $\alpha$-Methyldopa, $\alpha$-methyldopamine and $\alpha$-methylnoradrenaline behaved like dopa, dopamine and noradrenaline respectively in restoring the responses of tissues from reserpine-treated animals to stimulation of the sympathetic nerves to the rabbit ileum, the guinea-pig vas deferens and the cat nictitating membrane and in restoring responses to tyramine of the cat blood pressure and nictitating membrane, and the rat blood pressure. The potency of $\alpha$-methylnoradrenaline relative to noradrenaline ranged from one-half to one-ninth on various preparations. The results are discussed in relation to the antihypertensive action of $\alpha$-methyldopa.
\end{abstract}

The first observation that $\alpha$-methyldopa lowered the blood pressure of hypertensive patients was made by Oates, Gillespie, Udenfriend \& Sjoerdsma (1960) ; one of the most recent reports is by Smirk (1963). Although $\alpha$-methyldopa has now been established as a valuable drug for the treatment of hypertension, the pharmacological basis of its antihypertensive action is not completely understood.

$\alpha$-Methyldopa inhibits dopa decarboxylase both in vitro and in vivo (Sourkes, 1954 ; Dengler \& Reichel, 1957, 1958 ; Clark, 1959 ; Oates et al., 1960 ; Lovenberg, Weissbach \& Udenfriend, 1962); however it seems unlikely that this action of $\alpha$-methyldopa explains its antihypertensive property (Hess, Connamacher, Ozaki \& Udenfriend, 1961 ; Gillespie, Oates, Crout \& Sjoerdsma, 1962 ; Cannon, Whitlock, Morris, Angers \& Laragh, 1962).

In animals treated with $\alpha$-methyldopa the tissue stores of noradrenaline are depleted (Goldberg, DaCosta \& Ozaki, 1960 ; Hess et al., 1961 ; Porter, Totaro \& Leiby, 1961 ; Stone, Porter, Watson \& Ross, 1962a ; Stone, Ross, Wenger, Ludden, Blessing, Totaro \& Porter, 1962b ; Carlsson \& Lindqvist, 1962). The depletion is not a consequence of inhibition of dopa decarboxylase, since noradrenaline stores remain depleted for several days after the content of dopamine has returned to

\footnotetext{
* Present address: Research Division, Cleveland Clinic Foundation, Cleveland 6, Ohio, U.S.A.
} 
normal (Hess et al., 1961). Depletion of noradrenaline after administration of $\alpha$-methyldopa does not lead to a marked impairment of responses to stimulation of sympathetic nerves (Goldberg et al., 1960 ; Stone et al., 1962a, b).

$\alpha$-Methyldopa can serve as a substrate for dopa decarboxylase, being converted into $\alpha$-methyldopamine (Porter et al., 1961 ; Lovenberg et al., 1962 ; Gillespie et al., 1962 ; Porter \& Titus, 1963). In vivo the metabolism of $\alpha$-methyldopa proceeds further to produce $\alpha$-methylnoradrenaline (Carlsson \& Lindqvist, 1962) and $O$-methyl derivatives of $\alpha$-methylated catechol amines (Gillespie et al., 1962; Lauwers, Verstraete \& Joossens, 1963 ; Stott, Robinson \& Smith, 1963).

Recently, Day \& Rand (1963) suggested that, since $\alpha$-methyldopa is metabolized in the body to yield $\alpha$-methylnoradrenaline, the $\alpha$-methylnoradrenaline formed may enter storage sites for noradrenaline at sympathetic nerve endings, and then be released instead of noradrenaline as the sympathetic neurotransmitter. Carlsson $\&$ Lindqvist (1962) suggested that $\alpha$-methylated amines formed from $\alpha$-methyldopa could take over the role of normal catechol amines in the central nervous system. The lesser potency of $\alpha$-methylnoradrenaline in the cardiovascular system compared to noradrenaline would explain the decrease in blood pressure in hypertensive patients.

Our hypothesis for the mode of action of $\alpha$-methyldopa was based, in part, on experiments which we are reporting in this paper.

\section{METHODS}

Observations with preparations of isolated organs

Rabbit isolated ileum preparation. Segments of ileum together with periarterial sympathetic nerves were prepared by the method of Finkleman (1930). The segments were suspended in McEwen's (1956) solution at $37^{\circ} \mathrm{C}$, bubbled with $5 \%$ carbon dioxide in oxygen. The mesenteric artery and nerves were threaded through a bipolar platinum electrode of the type described by Burn \& Rand (1960a). Electrical stimulation was applied from an electronic stimulator using $2 \mathrm{msec}$ pulses at a frequency of 50 shocks/sec (unless otherwise stated); the voltage was supramaximal. Trains of stimuli were applied for $30 \mathrm{sec}$ every $4 \mathrm{~min}$.

Guinea-pig vas deferens preparation. The vas deferens with its hypogastric nerve was prepared by the method of Hukovic (1961) and suspended in McEwen's solution at $32^{\circ} \mathrm{C}$. Stimulation was with $2 \mathrm{msec}$ pulses at 20 shocks/ sec for 5 to $10 \mathrm{sec}$ every $2 \mathrm{~min}$; the voltage was supramaximal.

\section{Observations with whole animals}

Dogs and cats were anaesthetized with chloralose $(80 \mathrm{mg} / \mathrm{kg})$ together with pentobarbitone $(6 \mathrm{mg} / \mathrm{kg})$ injected intraperitoneally. Rabbits and guinea-pigs were anaesthetized with urethane (6 ml. $/ \mathrm{kg}$ of a $25 \%$ aqueous solution). Rats were injected with atropine $(1 \mathrm{mg}$, intraperitoneally), anaesthetized with ether and pithed by the method of Shipley \& Tilden (1947).

Cat nictitating membrane. The contractions of the nictitating membrane (usually the left) were recorded with an isotonic frontal writing lever exerting a tension of approximately $3 \mathrm{~g}$ and magnifying ten-times. The nerves from the cephalic pole of the superior cervical ganglion were dissected free and placed on bipolar platinum electrodes under liquid paraffin. Electrical stimulation was with $2 \mathrm{msec}$ pulses at frequencies ranging from 0.1 to 100 shocks/sec applied either for a constant time $(10 \mathrm{sec})$ or until a constant number of pulses had been delivered ( 200 or 300 in different experiments); supramaximal voltages were used. 
Measurement of arterial blood pressure. Blood pressure was recorded with a mercury manometer through a cannula inserted into a carotid artery or, in dogs, into a femoral artery. Blood pressure in rats and guinea-pigs was recorded with a Condon manometer.

Volume of cat spleen. Contractions of the spleen were recorded using the method of Burn (1952).

Treatment with reserpine. Intraperitoneal injections were given using either Serpasil (Ciba), which contains $2.5 \mathrm{mg} / \mathrm{ml}$. of reserpine in a proprietary vehicle, or a solution of $10 \mathrm{mg} / \mathrm{ml}$. of reserpine base in a $20 \%$ solution of ascorbic acid. The dose was $5 \mathrm{mg} / \mathrm{kg}$ of reserpine on the first day and 0 to $5 \mathrm{mg} / \mathrm{kg}$ on the second day according to the condition of the cat. The cat was used on the third day. Cats treated with reserpine had diarrhoea, and appeared ill and sedated (Withrington \& Zaimis, 1961), but the impression was gained that they were less ill after giving reserpine in ascorbic acid solution.

Rabbits, rats and guinea-pigs were injected intraperitoneally with $5 \mathrm{mg} / \mathrm{kg}$ of reserpine dissolved in ascorbic acid solution. Injections were given for 1 to 3 days and the animal was used the day after the last injection.

Treatment with $\alpha$-methyldopa. Solutions of $\alpha$-methyldopa (50 $\mathrm{mg} / \mathrm{ml}$.) were made in slightly acidified water.

In experiments with animals previously treated with $\alpha$-methyldopa, intraperitoneal injections were made daily or twice daily. The details of doses and durations of treatment are given in Results.

Optical isomers. The laevo-isomer of $\alpha$-methyldopa was used, and doses refer to the amino acid. The racemic form of $\alpha$-methyldopamine and the laevo-isomers of $\alpha$-methylnoradrenaline and of noradrenaline were used, and doses refer to the bases.

\section{RESULTS}

Effects of $\alpha$-methyldopa on responses to stimulation of sympathetic nerves

Rabbit isolated ileum preparation. $\alpha$-Methyldopa, in concentrations of 1 to 100 $\mu \mathrm{g} / \mathrm{ml}$. present in the organ-bath for periods as long as $3 \mathrm{hr}$, had no effect on the responses of the isolated ileum to stimulation of the sympathetic nerves either at frequencies giving less than a maximal relaxation (10 and 20 shocks/ $/ \mathrm{sec})$, or when maximal responses were obtained $(50$ shocks $/ \mathrm{sec})$; responses to noradrenaline (20 to $40 \mathrm{ng} / \mathrm{ml}$.) were also unaffected. The absence of an effect of $\alpha$-methyldopa on responses of the rabbit ileum to stimulation of the sympathetic nerves confirms the observation of Green (1962).

When $\alpha$-methyldopa was added to the organ-bath the fluid became pink in 15 to $30 \mathrm{~min}$ and darkened to purplish-black after 60 to $90 \mathrm{~min}$. To test whether the lack of action of $\alpha$-methyldopa was due to its oxidation an experiment was performed with two separate segments of ileum: to one $50 \mu \mathrm{g} / \mathrm{ml}$. of $\alpha$-methyldopa was added and left for $4 \mathrm{hr}$, and to the other the bath fluid was changed every 15 min and $50 \mu \mathrm{g} / \mathrm{ml}$. of $\alpha$-methyldopa was replaced each time. In neither experiment was there any diminution of responses to stimulation of the sympathetic nerves.

A higher concentration of $\alpha$-methyldopa $(500 \mu \mathrm{g} / \mathrm{ml}$.) depressed the amplitude of the pendulum movements of the ileum and impaired responses to stimulation of the sympathetic nerves and to noradrenaline; these effects were gradually eliminated after repeatedly washing the preparation.

Segments of ileum were taken from a rabbit which had been given intraperitoneal injections of $200 \mathrm{mg} / \mathrm{kg} /$ day of $\alpha$-methyldopa for 5 days, taking the ileum $6 \mathrm{hr}$ 
after the last dose. The responses of these segments to stimulation of the sympathetic nerves were no different from responses obtained in preparations from untreated rabbits.

Guinea-pig isolated vas deferens preparation. Concentrations of 1 to $100 \mu \mathrm{g} / \mathrm{ml}$. of $\alpha$-methyldopa present in the organ-bath for up to $3 \mathrm{hr}$ had no effect on the contraction of the vas deferens elicited by stimulation of the hypogastric nerves. After higher concentrations $(0.5$ to $1.0 \mathrm{mg} / \mathrm{ml}$.) there was a slight reduction in responses to nerve stimulation and to noradrenaline, but there was recovery after replacing fresh McEwen's solution in the bath (Fig. 1). A guinea-pig was given daily intraperitoneal injections of 150 to $200 \mathrm{mg} / \mathrm{kg}$ of $\alpha$-methyldopa for 3 days, and then both vasa deferentia were isolated. They responded to stimulation of the hypogastric nerves in a way indistinguishable from preparations from untreated guinea-pigs.

(a)

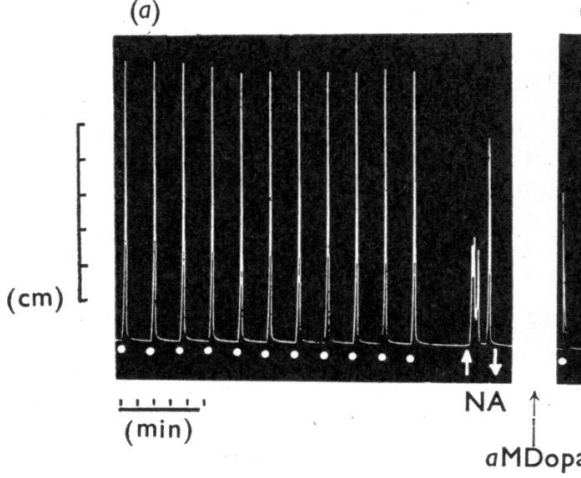

(b)

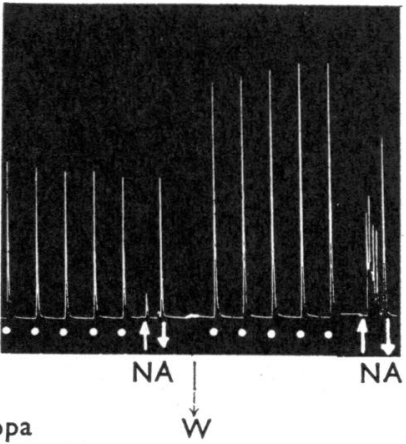

Fig. 1. Guinea-pig isolated vas deferens. Stimulation of hypogastric nerve (white dots) with $2 \mathrm{msec}$ pulses at 20 shocks/ $/ \mathrm{sec}$ for $10 \mathrm{sec}$ every $2 \mathrm{~min}$, except when noradrenaline (NA, $20 \mu \mathrm{g} / \mathrm{ml}$.) was present in the bath. (a) shows the initial responses; between $(a)$ and $(b), 0.5 \mathrm{mg} / \mathrm{ml}$. of $a$-methyldopa (aMDopa) was added to the organ-bath, $110 \mathrm{~min}$ before (b). The responses were reduced. After washing out and replacing with fresh McEwen's solution (W), the responses recovered rapidly. Time in min. Vertical scale in $\mathrm{cm}$.

Cat nictitating membrane. The responses of the nictitating membrane to various stimulus frequencies $(0.1$ to 100 shocks/sec) of the postganglionic cervical sympathetic nerve were established at intervals of about $2 \mathrm{hr}$. At other times the responses of the nictitating membrane were evoked at regular intervals, every 2 or $4 \mathrm{~min}$, using a frequency giving maximal responses, usually 20 or 50 shocks/ sec. Injections of 50 to $400 \mathrm{mg} / \mathrm{kg}$ of $\alpha$-methyldopa were given intravenously. There was a slowly developing impairment of responses of the nictitating membrane, particularly to responses evoked by low stimulus frequencies.

The results from one experiment are shown in Fig. 2. In this experiment there was a clear reduction in the height of the contractions of the nictitating membrane to low frequencies of nerve stimulation $2 \mathrm{hr}$ after injecting $\alpha$-methyldopa and a greater reduction $5 \mathrm{hr}$ after the injection. These effects were obtained so long 
(a)

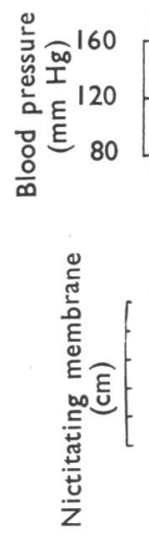

$(a)$

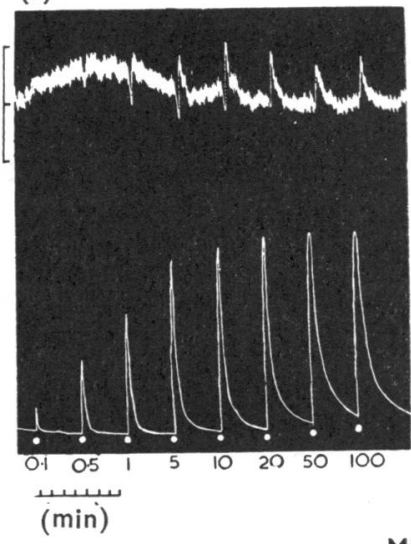

(b)

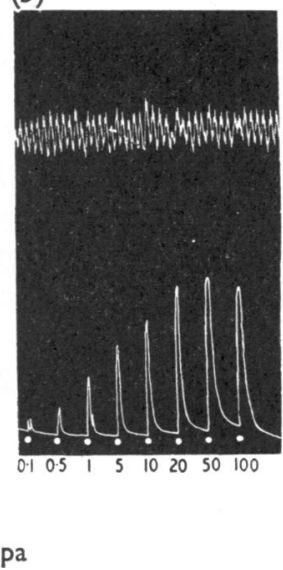

(c)

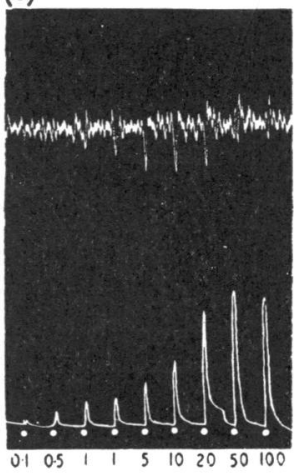

Fig. 2. Cat, $2.2 \mathrm{~kg}$. Top record : blood pressure; lower record: responses of nictitating membrane to stimulation of postganglionic sympathetic nerves (at white dots) with $2 \mathrm{msec}$ pulses, at frequencies indicated by the figures, for $10 \mathrm{sec}$ periods. a-Methyldopa (aMDopa) $(200 \mathrm{mg} / \mathrm{kg}$ ) was injected intravenously between panels $(a)$ and $(b)$. Panel $(b)$ was recorded $2 \mathrm{hr}$ and panel (c), $5 \mathrm{hr}$ after the injection. Between the panels the nerve was stimulated at 20 shocks/sec for $10 \mathrm{sec}$ every $4 \mathrm{~min}$. Time in min; calibration of blood pressure in $\mathrm{mm} \mathrm{Hg}$; contractions of nictitating membrane in $\mathrm{cm}$.

after injecting the $\alpha$-methyldopa that deterioration of the preparation may have contributed to the reduction in height of the contractions, but in similar experiments without the injection of $\alpha$-methyldopa there was considerably less impairment of responses of the nictitating membrane.

In two experiments responses to stimulation at various frequencies using a fixed duration of stimulation $(10 \mathrm{sec})$ were compared with responses to various stimulus frequencies using a fixed number (200 and 300) of shocks. With either method of stimulation the same result was obtained: a greater impairment of responses to low stimulus frequencies than to high frequencies.

Results similar to those in Fig. 2 were obtained in five experiments, but in three other experiments the effects were no greater than the deterioration in responses seen in control experiments.

The responses of the nictitating membranes to various stimulus frequencies of the sympathetic nerve were tested in cats previously treated wih $\alpha$-methyldopa (100 mg/ kg/day) for 3 or 4 days. The results were compared with those obtained from untreated cats using the same apparatus and, as far as possible, identical conditions. Fig. 3 shows that the mean height of contraction of the nictitating membrane was less in the cats treated with $\alpha$-methyldopa than in the control cats. At each stimulus frequency the difference between the means was significant at $\mathrm{P}<0.05$ (" $t$ " test).

Carotid sinus baroreceptor reflex. The reflex rise in blood pressure produced by occluding the common carotid arteries in cats was not impaired after $\alpha$-methyldopa (up to $200 \mathrm{mg} / \mathrm{kg}$ ). In a dog, however, the pressor response to occlusion of the 


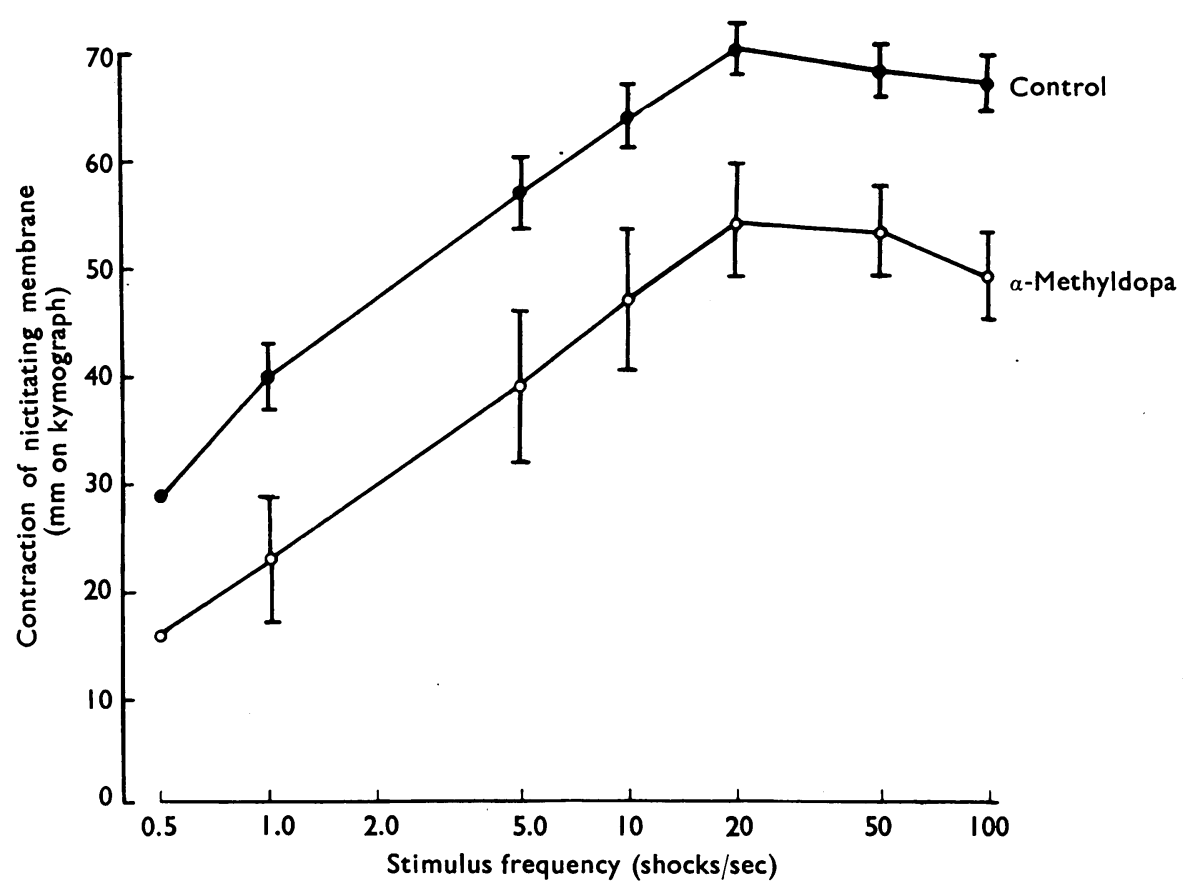

Fig. 3. Mean responses of cat nictitating membranes to stimulation of the postganglionic cervical sympathetic nerves at various frequencies (abscissa) using 2 msec shocks applied in groups of 200. The filled circles indicate results from four untreated cats. The empty circles are from four cats injected intraperitoneally with $100 \mathrm{mg} / \mathrm{kg} / \mathrm{day}$ of $\alpha$-methyldopa for 3 or 4 days, and used 16 to $21 \mathrm{hr}$ after the last injection. The vertical bars indicate the standard errors of the means.

(a)

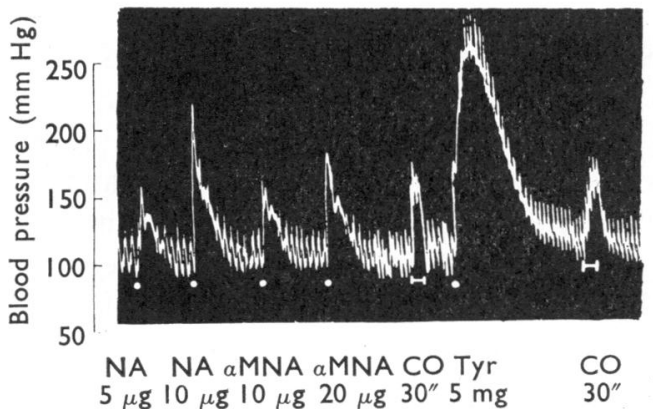

(b)

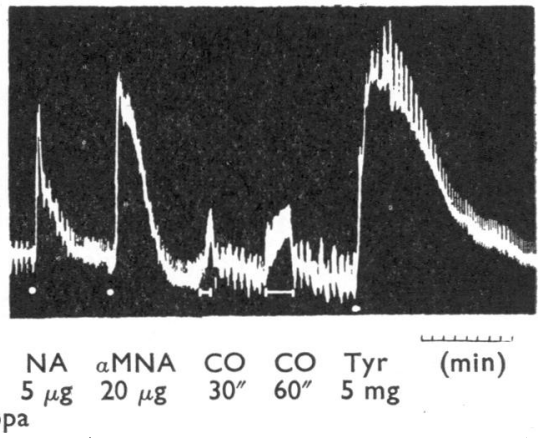

Fig. 4. Blood pressure of dog, $10 \mathrm{~kg}$. Drugs were injected intravenously in the doses indicated at the dots : NA, noradrenaline ; aMNA, a-methylnoradrenaline ; Tyr, tyramine. At the horizontal bars both common carotid arteries were occluded (CO) for the times indicated. Between panels (a) and (b) $200 \mathrm{mg} / \mathrm{kg}$ of $a$-methyldopa (aMDopa) was injected intravenously and (b) was record ed $110 \mathrm{~min}$ later. Time in $\mathrm{min}$. Blood pressure in $\mathrm{mm} \mathbf{H g}$. 
carotid arteries was delayed, but the height of the pressor response was as great as before $\alpha$-methyldopa (Fig. 4).

\section{Effects of $\alpha$-methyldopa on responses to noradrenaline and tyramine}

In the cat intravenous injections of 100 to $250 \mathrm{mg} / \mathrm{kg}$ of $\alpha$-methyldopa had inconsistent effects on responses of the blood pressure and the nictitating membrane to noradrenaline and to tyramine. In three experiments the response to noradrenaline was potentiated and in three experiments it was unaffected. In four experiments the pressor response to tyramine was unaffected and in one it was slightly reduced. Kroneberg \& Stoepel (1963) found that $500 \mathrm{mg} / \mathrm{kg}$ of $\alpha$-methyldopa did not affect pressor responses to tyramine in the cat. After $\alpha$-methyldopa, tyramine caused an increased contraction of the nictitating membrane in two experiments, in two experiments the contraction was unaffected and in one it was slightly reduced.

In cats treated with $\alpha$-methyldopa ( $100 \mathrm{mg} / \mathrm{kg} /$ day) for 3 or 4 days, the responses to noradrenaline ( 2 to $4 \mu \mathrm{g}$ ) were clearly greater than in untreated cats, and responses to tyramine (1 to $3 \mathrm{mg}$ ) were similar to, or slightly greater than, responses in untreated cats. After an intravenous infusion of noradrenaline $(0.4 \mathrm{mg}$ in $20 \mathrm{~min})$ the pressor responses to noradrenaline and to tyramine were reduced.

In the dog, pressor responses to noradrenaline, $\alpha$-methylnoradrenaline and to tyramine were potentiated after $200 \mathrm{mg} / \mathrm{kg}$ of $\alpha$-methyldopa (Fig. 4).

In our experiments the blood pressure was not appreciably altered by $\alpha$-methyldopa, but Goldberg et al. (1960) reported that the blood pressure fell in unanaesthetized dogs.

Our colleague, J. Wilson, has made observations on rats treated with $400 \mathrm{mg} / \mathrm{kg}$ of $\alpha$-methyldopa every $8 \mathrm{hr}$ for 2 days, the rats being used 3 to $6 \mathrm{hr}$ after the last injection. In these rats the pressor response to tyramine $(50 \mu \mathrm{g})$ was normal, whereas the response to noradrenaline was greater than in untreated rats.

Effects of $\alpha$-methyldopa, $\alpha$-methyldopamine and $\alpha$-methylnoradrenaline after treatment of animals with reserpine

Rabbit isolated ileum preparation. Segments of ileum taken from rabbits treated with reserpine responded to stimulation of their periarterial sympathetic nerves with incomplete relaxations, or else they contracted. After treatment of the preparation in the organ-bath with $\alpha$-methyldopa $(50 \mu \mathrm{g} / \mathrm{ml}$.) for $1 \mathrm{hr}$ or more, and then replacement with fresh McEwen's solution in the bath, the responses to stimulation of the sympathetic nerves were partly restored towards the responses seen with segments of ileum from untreated rabbits. Fig. 5 shows that both $\alpha$-methyldopa and (-)-dopa improved the responses to a similar extent.

Responses of segments of ileum from rabbits treated with reserpine to stimulation of the sympathetic nerves were clearly enhanced after treatment of the preparations in the organ-bath for 20 to $30 \mathrm{~min}$ with $10 \mu \mathrm{g} / \mathrm{ml}$. of $\alpha$-methyldopamine or $\alpha$-methylnoradrenaline. The restoration of responses produced by these $\alpha$-methylated compounds was as good as or better than the restoration produced by dopamine or noradrenaline. 
(a)

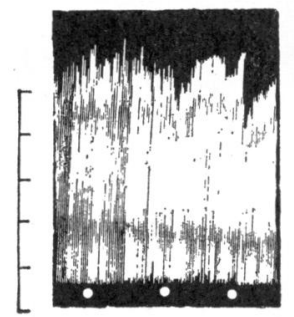

(cm) 10 (b)

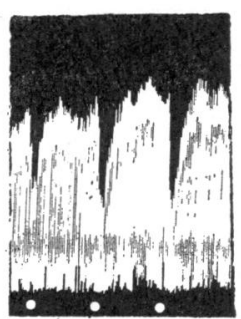

(c)

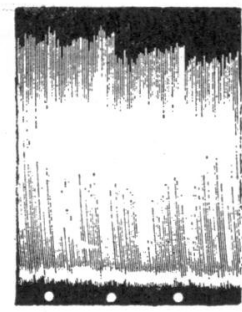

(d)

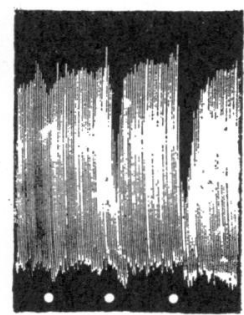

$\begin{array}{lllllll}10 & 20 & 50 & \uparrow & 10 & 20 & 50\end{array}$

Fig. 5. Responses of two segments of ileum with their sympathetic nerves taken from a rabbit treated with reserpine for 2 days. At the white dots the nerves were stimulated at the frequencies indicated for $25 \mathrm{sec}$. Between each period of stimulation 4 min elapsed. At first, the preparations failed to respond ( $a$ and $c$ ) but, after treatment with $50 \mu \mathrm{g} / \mathrm{ml}$. of $a$-methyldopa ( $a$ MDopa, between $a$ and $b$ ) or $50 \mu \mathrm{g} / \mathrm{ml}$. of dopa (between $c$ and $d$ ) left in contact for $85 \mathrm{~min}$, responses to stimulation were improved. Time in min. Vertical scale in $\mathrm{cm}$.

Guinea.pig vas deferens preparation. Neither $\alpha$-methyldopa nor (-)-dopa, in concentrations up to $50 \mu \mathrm{g} / \mathrm{ml}$, affected the responses of isolated vasa deferentia from reserpinized guinea-pigs to stimulation of their hypogastric nerves. However, $\alpha$-methylnoradrenaline (5 to $10 \mu \mathrm{g} / \mathrm{ml}$.) or $\alpha$-methyldopamine (10 to $20 \mu \mathrm{g} / \mathrm{ml}$.) temporarily enhanced the responses of the vas deferens to about the same extent as did the same concentrations of noradrenaline or dopamine. That neither amino acid restored the responses of the vas deferens isolated from guinea-pigs treated with reserpine to stimulation of the hypogastric nerve, although the corresponding amines were able to restore responses, would be explained if the vas deferens did not contain significant amounts of accessible dopa decarboxylase.

Cat nictitating membrane and blood pressure. In cats which had been treated with reserpine, infusions of $\alpha$-methyldopa were as effective as infusions of dopa in restoring responses to tyramine and to stimulation of the sympathetic nerves to the nictitating membrane. The results from one experiment with $\alpha$-methyldopa $(60 \mathrm{mg})$ are shown in Fig. 6. At the start of the experiment, $4 \mathrm{mg}$ of tyramine caused only a small rise in blood pressure, $1 \mu \mathrm{g}$ of noradrenaline caused a conspicuous rise in blood pressure and stimulation of the sympathetic nerve to the nictitating membrane caused a contraction of about one-third that seen in normal cats: these results are typical for a cat treated with reserpine (Burn \& Rand, 1958). After the infusion of $\alpha$-methyldopa the pressor response to tyramine was enhanced, although there was no restoration of contractions of the nictitating membrane in response to tyramine. However, it has been our experience that dopa sometimes failed to restore contractions of the nictitating membrane in response to tyramine in cats treated with reserpine, while pressor responses to tyramine were regularly enhanced. The responses of the nictitating membrane to stimulation of the cervical sympathetic nerve were enhanced after infusion of $\alpha$-methyldopa. Pressor responses to noradrenaline were usually slightly enhanced after administration of $\alpha$-methyldopa: in this respect $\alpha$-methyldopa differs from dopa, which reduces the responses 


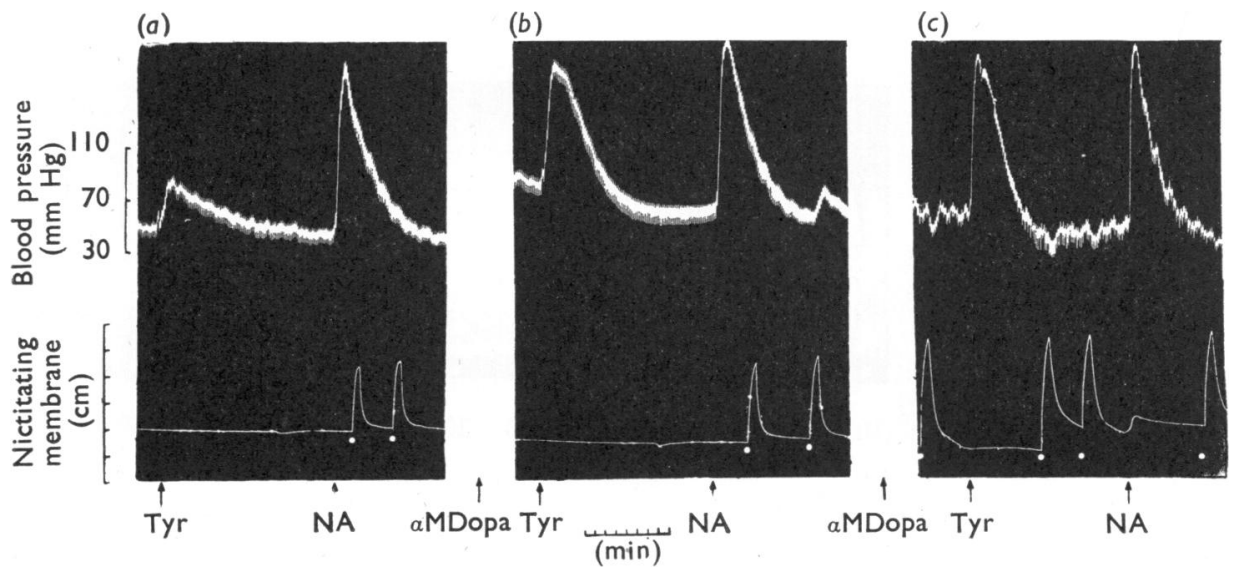

Fig. 6. Blood pressure (upper record) and contractions of nictitating membrane (lower record) from cat $(2.0 \mathrm{~kg})$ treated with reserpine. At the white dots the postganglionic cervical sympathetic nerves were stimulated at 20 shocks/ $/ \mathrm{sec}$ for $10 \mathrm{sec}$. Intravenous injections of tyramine ( $4 \mathrm{mg}$ at Tyr) and noradrenaline ( $1 \mu \mathrm{g}$ at NA) are indicated. Between $(a)$ and $(b), 60 \mathrm{mg}$ of a-methyldopa ( $a \mathrm{MDopa}$ ) were infused in $20 \mathrm{ml}$. of solution during $20 \mathrm{~min}$. Between $(b)$ and (c), 85 min later, another infusion of a-methyldopa was given. Time in min. Blood pressure in $\mathrm{mm} \mathrm{Hg}$. Nictitating membrane contractions in $\mathrm{cm}$.

to noradrenaline in cats treated with reserpine. Kroneberg \& Stoepel (1963) reported that $\alpha$-methyldopa $(500 \mathrm{mg} / \mathrm{kg})$, infused into cats treated with reserpine, increased the actions of tyramine on the blood pressure and the nictitating membrane, that responses to noradrenaline were unchanged, and that contractions of the nictitating membrane in response to stimulation of the sympathetic nerves were not increased.

The infusion of $\alpha$-methyldopamine (Fig. 7) and of $\alpha$-methylnoradrenaline (Fig. 8) restored the responses to tyramine on the blood pressure and nictitating membrane of cats treated with reserpine and increased the responses of the nictitating membrane to stimulation of the sympathetic nerves. The pressor responses to noradrenaline were slightly enhanced after infusions of $\alpha$-methyldopamine and $\alpha$-methylnoradrenaline: this contrasts with the effects of infusions of noradrenaline (Burn $\&$ Rand, 1958) and of dopamine, which reduce the pressor action of noradrenaline. In other respects the effects of infusions of $\alpha$-methyldopamine and $\alpha$-methylnoradrenaline were similar to those of dopamine and noradrenaline respectively. Thus the dopamines gave a better restoration of the responses of the nictitating membrane to nerve stimulation and the restoration persisted longer than with the noradrenalines (compare Burn \& Rand, 1960b).

Rat blood pressure. In pithed rats treated with reserpine the pressor responses to tyramine $(100 \mu \mathrm{g})$ were considerably less than were seen in pithed rats not treated with reserpine. After an infusion of $\alpha$-methyldopa $(1 \mathrm{mg}$ in $20 \mathrm{~min})$ the pressor responses to tyramine were increased and remained at their increased height for at least $1.5 \mathrm{hr}$ (Fig. 9). Infusion of $\alpha$-methyldopamine (200 $\mu \mathrm{g}$ in $20 \mathrm{~min})$ or $\alpha$-methylnoradrenaline (5 $\mu \mathrm{g}$ in $20 \mathrm{~min}$ ) also restored responses to tyramine in rats treated with reserpine, but the restorations did not persist as long as after infusions of $\alpha$-methyldopa. 
(a)

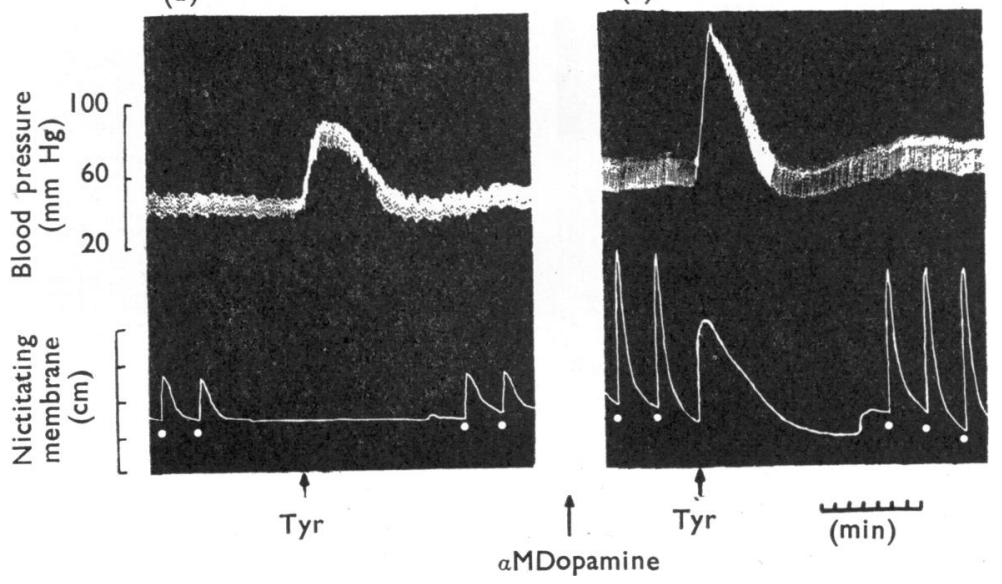

Fig. 7. Blood pressure (upper record) and contractions of nictitating membrane (lower record) of cat $(1.9 \mathrm{~kg})$ treated with reserpine. At the white dots the postganglionic cervical sympathetic nerves were stimulated at 20 shocks/sec for $15 \mathrm{sec}$. At Tyr, $4 \mathrm{mg}$ of tyramine was injected intravenously. Between $\mathrm{A}$ and $\mathrm{B}, 10 \mathrm{mg}$ of a-methyldopamine (aMDopamine) was infused in $10 \mathrm{ml}$. of solution during $20 \mathrm{~min}$. Time in min. Blood pressure in $\mathrm{mm} \mathrm{Hg}$. Nictitating membrane contractions in $\mathrm{cm}$.

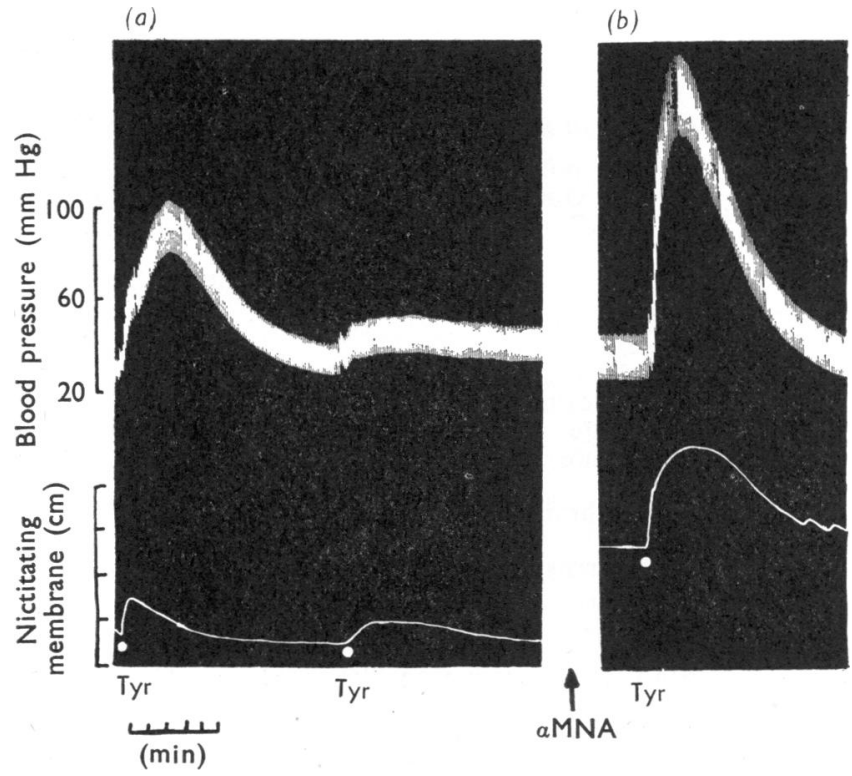

Fig. 8. Blood pressure (upper record) and contractions of nictitating membrane (lower record) of cat $(3.2 \mathrm{~kg})$ treated with reserpine. At Tyr, $4 \mathrm{mg}$ of tyramine were injected intravenously. Between $(a)$ and $(b), 1 \mathrm{mg}$ of $a$-methylnoradrenaline (aMNA) was infused in $20 \mathrm{ml}$. of solution during $20 \mathrm{~min}$. Time in min. Blood pressure in $\mathrm{mm} \mathrm{Hg}$. Nictitating membrane contractions in $\mathrm{cm}$. 


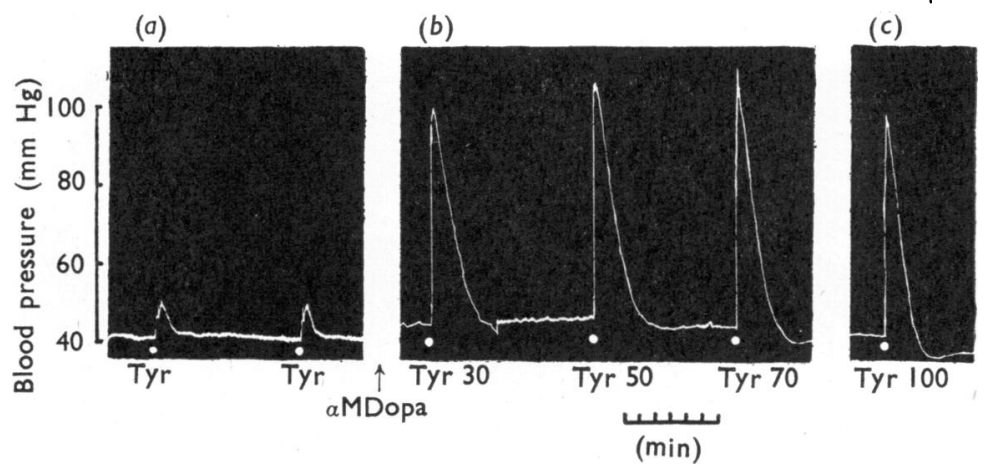

Fig. 9. Blood pressure of pithed rat treated with reserpine. Between panels $(a)$ and $(b), 1 \mathrm{mg}$ of $a$-methyldopa (aMDopa) in $1 \mathrm{ml}$. of solution was infused during $20 \mathrm{~min}$. Tyramine $(100 \mu \mathrm{g})$ was injected intravenously at Tyr. In panels $(b)$ and $(c)$ the figures refer to the time in min after the infusion of a-methyldopa. Time in min. Blood pressure in $\mathrm{mm} \mathrm{Hg}$.

\section{Potency of $\alpha$-methylnoradrenaline relative to noradrenaline}

The comparison of the potencies of $\alpha$-methylnoradrenaline and of noradrenaline was carried out by determining the responses to a number of doses of each substance. For doses which produced less than half of the maximal responses, the log dose/ response lines did not differ significantly from parallel. The results are summarized in Table 1. In all the preparations tested $\alpha$-methylnoradrenaline was less active than noradrenaline.

\section{TABLE 1}

RELATIVE POTENCY OF NORADRENALINE AND a-METHYLNORADRENALINE Potency ratios are the ratios of the potencies of noradrenaline compared with those of $a$-methylnoradrenaline. * From Goodman \& Gilman (1955). † From Ahlquist (1948)

\section{Preparation}

Cat blood pressure

Dog blood pressure

Rat (spinal) blood pressure

Guinea-pig blood pressure

Rabbit blood pressure

Human blood pressure

Cat spleen volume

Cat nictitating membrane

Rabbit perfused ear

Guinea-pig vas deferens
No. of

experiments

\begin{tabular}{ll}
4 & $1 \cdot 9$ \\
4 & $1 \cdot 9$ \\
3 & $2 \cdot 9$ \\
2 & $6 \cdot 2$ \\
2 & $8 \cdot 5$ \\
\hline 1 & $4 *$ \\
\hline 2 & 2 \\
1 & $2 \dagger$ \\
& 8 \\
& 2
\end{tabular}

In cats and rats treated with reserpine the pressor responses to $\alpha$-methylnoradrenaline and to noradrenaline were greater than in the control animals, but the relative potency was unchanged.

\section{Comparison of $\alpha$-methyldopamine with dopamine}

Dopamine antagonizes the action of guanethidine in blocking the responses of the rabbit ileum to stimulation of the sympathetic nerves, but dopa and noradrenaline 
were ineffective (Day, 1962). $\alpha$-Methyldopamine shared this action of dopamine, but neither $\alpha$-methyldopa nor $\alpha$-methylnoradrenaline affected the blocking action of guanethidine.

\section{DISCUSSION}

Although $\alpha$-methyldopa is efficacious in relieving hypertension it differs from other antihypertensive drugs in that it has only slight effects on the responses to simulation of sympathetic nerves. We found that $\alpha$-methyldopa reduced but did not abolish contractions of the cat nictitating membrane in response to stimulation of the sympathetic nerves. Responses to stimulation of the sympathetic nerves of the rabbit isolated ileum and the guinea-pig isolated vas deferens were diminished only in the presence of high concentrations of $\alpha$-methyldopa, when the responses to noradrenaline were also diminished. Goldberg et al. (1960) did not observe any impairment of the response of the heart to stimulation of the presynaptic fibres to the stellate ganglion in dogs treated with $\alpha$-methyldopa, and Stone et al. $(1962 \mathrm{a}, \mathrm{b})$ were unable to detect an effect of $\alpha$-methyldopa on responses to sympathetic stimulation in experimental animals. The clinical findings are that $\alpha$-methyldopa causes a slight postural hypertension (Onesti, Brest, Novack \& Moyer, 1962 ; Gillespie et al., 1962 ; Bayliss \& Harvey-Smith, 1962), abolition of overshoot in the Valsalva manœuvre (Dollery \& Harington, 1962) and a decreased cardiovascular response to exercise (Sannerstedt, Varnauskas \& Werkö, 1962). These observations on patients suggest an impairment of sympathetically mediated cardiovascular reflexes, and Gillespie et al. (1962) reported failure of ejaculation which may also have been due to impairment of sympathetic nerves.

The most striking pharmacological action of $\alpha$-methyldopa which we have observed is the restoration of responses to stimulation of sympathetic nerves and to tyramine when these responses have been impaired as a result of treatment with reserpine. Infusions of $\alpha$-methyldopa, $\alpha$-methyldopamine and $\alpha$-methylnoradrenaline into cats treated with reserpine usually caused a slight increase in the pressor response to noradrenaline. However, it is unlikely that this slightly increased reactivity of the cardiovascular system was in itself responsible for the greatly increased pressor responses to tyramine (see Fig. 6). Kroneberg \& Stoepel (1963) found that $\alpha$-methyldopa increased the pressor responses to tyramine in cats treated with reserpine without any increase in the pressor responses to noradrenaline.

Responses to sympathetic nerve stimulation and to tyramine depend on the presence of stores of noradrenaline in the tissue. Depletion of these stores by reserpine causes a loss of responses. Repletion of the stores after an infusion of noradrenaline, or a substance which yields noradrenaline when it has been metabolized in the body, results in a restoration of responses (Burn \& Rand, 1960b). The effects of $\alpha$-methyldopa in restoring responses to stimulation of sympathetic nerves and to injections of tyramine after treament with reserpine closely resemble the effects of dopa in restoring these responses. $\alpha$-Methyldopa, like dopa, is a substrate for dopa decarboxylase, this enzyme producing $\alpha$-methyldopamine and dopamine respectively (see Introduction for references). It is difficult to explain the restoration of responses after giving $\alpha$-methyldopa, $\alpha$-methyldopamine or $\alpha$-methylnoradrenaline by assuming that noradrenaline is formed; there are no 
published results indicating that the $\alpha$-methyl group can be removed. Furthermore, the tissue stores of noradrenaline are depleted after administration of $\alpha$-methyldopa metabolites (see Introduction for references). These observations are compatible with the hypothesis that $\alpha$-methylnoradrenaline can serve, in place of noradrenaline, to mediate responses to stimulation of sympathetic nerves and to tyramine.

Responses to tyramine depend on the presence of noradrenaline bound in stores in the tissue, the noradrenaline being displaced from the stores by tyramine and then acting on the effector cells (Burn \& Rand, 1958). Despite the fact that $\alpha$-methyldopa depletes tissues of noradrenaline, we found that responses to tyramine in the cat were not impaired after either a single dose of $\alpha$-methyldopa or doses given for several days, and Goldberg et al. (1960) found that the cardiovascular actions of tyramine in dogs were not affected by $\alpha$-methyldopa. However, Stone et al. (1962a) reported that pressor responses to phenethylamine and to amphetamine were reduced or abolished after treatment with $\alpha$-methyldopa, although Stone $e t$ al. (1962b) reported that responses to phenethylamine were not affected after a single injection of $\alpha$-methyldopa. In man the transient pressor response following intravenous injection of guanethidine, a response mediated by noradrenaline displaced from its stores in the tissues (Gillis \& Nash, 1961), is not diminished after treatment with $\alpha$-methyldopa (Wilson, Fisher \& Kirkendall, 1961 ; Dollery \& Harington, 1962).

In animals treated with $\alpha$-methyldopa the stores of noradrenaline are depleted, but $\alpha$-methylnoradrenaline is present in the tissues (Carlsson \& Lindqvist, 1962), which suggests that tyramine acts in animals treated with $\alpha$-methyldopa by displacing $\alpha$-methylnoradrenaline from stores normally occupied by noradrenaline.

There are observations that the actions of $\alpha$-methyldopa are exerted only after it has been metabolized. Davis, Drain, Harington, Lazare \& Urbanska (1963) reported that $\alpha$-methyldopa no longer depleted tissues of normal catechol amines, nor did it have a hypotensive action, if its decarboxylation was prevented by giving a potent inhibitor of dopa decarboxylase. The dextro-isomer of $\alpha$-methyldopa is not a substrate for dopa decarboxylase and it does not deplete noradrenaline from tissues (Porter et al., 1961), it has no antihypertensive action in man (A. Sjoerdsma, personal communication to Stone et al., 1962a), and it does not restore responses to tyramine in cats treated with reserpine (Kroneberg \& Stoepel, 1963). Tissue stores of noradrenaline are depleted after administration of $\alpha$-methyldopamine and $\alpha$-methylnoradrenaline (Hess et al., 1961 ; Porter et al., 1961), these compounds being metabolic derivatives of $\alpha$-methyldopa.

Our results and deductions might have some bearing on the therapeutically useful action of $\alpha$-methyldopa in relieving hypertension. Treatment with $\alpha$-methyldopa leads to the formation of $\alpha$-methylnoradrenaline which is then bound in tissues, and this compound can serve in place of noradrenaline to mediate responses to sympathetic nerve impulses. However $\alpha$-methylnoradrenaline is less potent than noradrenaline. It may be that in hypertensive patients treated with $\alpha$-methyldopa the substitution of $\alpha$-methylnoradrenaline for noradrenaline diminishes the effectiveness of sympathetic impulses to the blood vessels. Nevertheless responses to sympathetic impulses persist, so that severe postural hypotension and other unpleasant consequences of complete sympathetic blockade occur only rarely. 
We are indebted to Dr F. G. Clayton (Merck, Sharp \& Dohme) for a gift of $\alpha$-methyldopa (Aldomet), to Dr K. Pfister (Merck \& Co., Rahway, New Jersey, U.S.A.) for gifts of $\alpha$-methyldopa and $\alpha$-methyldopamine, to Dr M. Tainter (Winthrop Sterling Drugs, New York, U.S.A.) for a gift of $\alpha$-methylnoradrenaline and to $\mathrm{Dr} \mathrm{A}$. B. Tattersall for a gift of reserpine. One of us (M. D. D.) is grateful to the Medical Research Council for financial support.

\section{REFERENCES}

AHLQuist, R. P. (1948). A study of the adrenotropic receptors. Amer. J. Plyricl., 153; $\leq \mathcal{E}$-(CC BAYLiss, R. I. S. \& HARVEY-SMITH, E. A. (1962). Methyldopa in the treatment of hypertension. Lancet, i, 763-768.

BURN, J. H. (1952). Practical Pharmacology. Oxford: Blackwell.

BURN, J. H. \& RAND, M. J. (1958). The action of sympathomimetic amines in animals treated with reserpine. J. Physiol. (Lond.), 144, 314-336.

BURN, J. H. \& RAND, M. J. (1960a). The relation of circulating noradrenaline to the effect of sympathetic stimulation. J. Physiol. (Lond.), 150, 295-305.

BURN, J. H. \& RAND, M. J. (1960b). The effect of precursors of noradrenaline on the response to tyramine and sympathetic stimulation. Brit. J. Pharmacol., 15, 47-55.

Cannon, P. J., Whitlock, R. T., Morris, R. C., ANGers, M. \& LARagh, J. H. (1962). Effect of alpha-methyldopa in severe and malignant hypertension. J. Amer. med. Ass., 179, 673-681.

CARLSSON, A. \& LINDQvist, M. (1962). In vivo decarboxylation of a-methylDOPA and a-methy, metatyrosine. Acta physiol. scand., 54, 87-94.

CLARK, W. G. (1959). Studies on inhibition of $l$-dopa decarboxylase in vitro and in vivo. Pharmacol. Rev., 11, 330-349.

Davis, R. A., Drain, D. J., Harlington, M., Lazare, R. \& Urbanska, A. (1963). Life Sciences, 3, 193-197. Cited in Rossum \& HURKMANS (1963).

DAY, M. D. (1962). Effect of sympathomimetic amines on the blocking action of guanethidines bretylium and xylocholine. Brit. J. Pharmacol., 18, 421-439.

DAY, M. D. \& RAND, M. J. (1963). A hypothesis for the mode of action of $a$-methyldopa in relieving hypertension. J. Pharm. Pharmacol., 15, 221-224.

DeNGleR, H. \& ReICHEL, G. (1957). Die Beeinflussung der Blutdruckwirkung von Dopa und Dopl, durch einen Decarboxylase-Inhibitor. Naunyn-Schmiedeberg's Arch. exp. Path. Pharmak., 232, 324-326.

DENGLER, H. \& REICHEL, G. (1958). Hemmung der Dopadecarboxylase durch a-Methyldopa in vivo. Naunyn-Schmiedeberg's Arch. exp. Pa'h. Pharmak., 234, 275-281.

DOLLERY, C. T. \& HARINGTON, M. (1962). Methyldopa in hypertension. Clinical and pharmacological studies. Lancet, $\mathrm{i}, 759-763$.

FinkLEMAN, B. (1930). On the nature of inhibition in the intestine. J. Physiol. (Lond.), 70, 145-157.

Gillespie, L., OATrs, J. A., Crout, J. R. \& SJokrdsma, A. (1962). Clinical and chemical studies with $a$-methyldopa in patients with hypertension. Circulation, 25, 281-291.

Gillrs, C. N. \& NASH, C. W. (1961). The initial pressor actions of bretylium toxylate and guanethidine sulfate and their relation to release of catecholamines. J. Pharmacol. exp. Ther., 134, $1-7$.

GoldBerg, L. I., DACosta, F. M. \& OzAKI, M. (1960). Actions of the decarboxylase inhibitor. a-methyl-3,4-dihydroxyphenylalanine, in the dog. Nature (Lond.), 188, 502-504.

Goodman, L. S. \& Gilman, A. (1955). The Pharmacological Basis of Therapeutics, 2nd ed. New York: Macmillan.

GreEN, A. F. (1962). Antihypertensive drugs. Advanc. Pharmacol., 1, 161-225.

Hess, S. M., ConNAmacher, R. H., Ozaki, M. \& UDENFriend, S. (1961). The effects of $a$-methyldopa and a-methyl-meta-tyrosine on the metabolism of norepinephrine and serotonin in vivo. J. Pharmacol. exp. Ther., 134, 129-138.

Huković, S. (1961). Responses of the isolated sympathetic nerve-ductus deferens preparation of the guinea-pig. Brit. J. Pharmacol., 16, 188-194.

KRONEBERG, G. \& STOEPEL, K. (1963). Der Einfluss von a-methyl-dopa auf die Tyraminwirkung an mit Reserpin vorbehandelten Katzen. Experientia (Basel), 19, 252-253.

LAUWERS, P., Verstraete, M. \& JOOSSENS, J. V. (1963). Methyldopa in the treatment of hypertension. Brit. med. J., i, 295-300.

LOVENBERG, W., WEISSBACH, H. \& UDENFRIEND, S. (1962). Aromatic $l$-amino acid decarboxylase. J. biol. Chem., 237, 89-93.

MCEWEN L., M. (1956). The effect on the isolated rabbit heart of vagal stimulation and its modification by cocaine, hexamethonium and ouabain. J. Physiol. (Lond.), 131, 678-689. 
OAtes, J. A., Gillespie, L., Udenfriend, S. \& SJoersdma, A. (1960). Decarboxylase inhibition and blood pressure reduction by a-methyl-3,4-dihydroxy-dl-phenylalanine. Science, 131, 1890-1891.

Onesti, G., Brest, A. N., NovaCK, P. \& MoYer, J. H. (1962). Pharmacodynamic effects and clinical use of alpha-methyldopa in the treatment of essential hypertension. Amer. J. Cardiol., 9, 863-867.

PORTER, C. C. \& TITUS, D. C. (1963). Distribution and metabolism of methyldopa in the rat. J. Pharmacol. exp. Ther., 139, 77-87.

Porter, C. C., Totaro, J. A. \& Leiby, C. M. (1961). Some biochemical effects of a-methyl-3,4dihydroxyphenyl-alanine and related compounds in mice. J. Pharmacol. exp. Ther., 134, 139-145.

Rossum, J. M. VAN \& HuRkmans, J. A. T. M. (1963). Reversal of the effect of a-methyldopa by monoamine oxidase inhibitors. J. Pharm. Pharmacol., 15, 493-499.

SANNERSTEDT, R., VARNAUSKas, E. \& Werkö, L. (1962). Hemodynamic effects of methyldopa ('aldomet ') at rest and during exercise in patients with arterial hypertension. Acta med. scand., 171, 75-82.

Shipley, R. E. \& Tilden, J. T. (1947). Pithed rat preparation suitable for assaying pressor substances. Proc. Soc. exp. Biol. (N.Y.), 64, 453-455.

SMIRK, H. (1963). Hypotensive action of methyldopa. Brit. med. J., i, 146-151.

SOURKES, T. L. (1954). Inhibition of dihydroxyphenylalanine decarboxylase by derivatives of phenylalanine. Arch. Biochem., 51, 444-456.

Stone, C. A., Porter, C. C., Watson, L. S. \& Ross, C. A. (1962a). Pharmacology of decarboxylase inhibitors. In Hypertension: Recent Advances, pp. 417-423, ed. BREST, A. N. \& MOYER, J. H. London: Kimpton.

Stone, C. A., Ross, C. A., Wenger, H. C., Ludden, C. T., Blessing, J. A., Totaro, J. A. \& Porter, C. C. (1962b) . Effect of $a$-methyl-3,4-dihydroxyphenylalanine (methyldopa), reserpine and related agents on some vascular responses in the dog. J. Pharmacol. exp. Ther., 136, 80-88.

StotT, A. W., Robinson, R. \& SMITH, P. (1963). Total medadrenaline excretion in patients treated with a-methyldopa. Lancet, i, 266-267.

Wilson, W. R., Fisher, F. D. \& Kirkendall, W. M. (1961). The acute hemodynamic effects of a-methyl-dopa in man. J. clin. Invest., 40, 1089.

Withrington, P. \& Zaimis, E. (1961). The reserpine-treated cat. Brit. J. Pharmacol., 17, $380-391$. 